\title{
INTEGRATIVE METHODOLOGY FOR THE IDENTIFICATION OF GROUNDWATER FLOW PATTERNS: APPLICATION IN A SEMI-ARID REGION OF MEXICO
}

\author{
NAVARRO-SOLÍS, O.$^{1 *}$ - GONZÁLEZ-TRINIDAD, J. ${ }^{1}$ - JÚNEZ-FERREIRA, H. E. ${ }^{1}$ - \\ CARDONA, A. ${ }^{2}$ - BAUTISTA-CAPETILLO, C. F. ${ }^{1}$ \\ ${ }^{1}$ Doctorado en Ciencias de la Ingeniería, Universidad Autónoma de Zacatecas \\ Av. Ramón López Velarde No. 801, Carretera a la Bufa, Zacatecas, México. C.P. 98000 \\ (tel: + 492-924-2432; fax: +492-925-6690 ext.1613; Júnez-Ferreira H. E. e-mail: \\ hejunez@hotmail.com; Bautista-Capetillo C.F.e-mail: baucap@uaz.edu.mx; González- \\ Trinidad J.e-mail: jgonza@uaz.edu.mx) \\ ${ }^{2}$ Facultad de Ingeniería, Área de Ciencias de la Tierra, \\ Universidad Autónoma de San Luis Potosí, Av. Niño Artillero No. 801, \\ San Luis Potosí, México CP 78920 \\ hidrogeoquimica@gmail.com \\ *Corresponding author \\ e-mail: navarrosoliso@yahoo.com.mx \\ (Received $21^{\text {st }}$ Jul 2016; accepted $10^{\text {th }}$ Oct 2016)
}

\begin{abstract}
Generating knowledge to explain the dynamics and physicochemical characteristics of groundwater is essential to ensure its availability for different uses. Therefore, in this article we propose an integrated methodology that may help to define the flow patterns governing the movement of groundwater in a semiarid region of Mexico. The methodology incorporates hydrogeochemical characterization with the application of flow systems theory, the behaviour of arsenic and fluoride as indicators of the quality for human consumption and a correlation matrix to identify potential areas of recharge-discharge; these variables are grouped in Geographic Information Systems (GIS). The results explain how the movement of groundwater was influenced by the dissolution of silicates with the geochemical evolution of arsenic under two natural conditions; however, in one of these conditions, the mobility was facilitated by the presence of mining activities, whereas fluoride exhibited two situations, one natural and the other anthropogenic. Four hydrogeochemical facies were manifested in three flow patterns, with a potential recharge zone in the west of the study area, a discharge zone in the east and a mixture flowing to the northwest. We concluded that the proposed methodology represents a tool for facilitating understanding of the movement of groundwater.
\end{abstract}

Keywords: water quality, GIS, recharge-discharge area, groundwater dynamics

\section{Introduction}

In recent years, worldwide accessibility to groundwater has declined while pollution has increased in such a manner that ensuring sustainable management requires research on the processes that determine the quantity and quality of groundwater systems, as well as the potential impacts of its use (Garfias et al., 2010). In Mexico, the demand for groundwater has grown considerably; it comprises almost $40 \%$ of Mexico's water consumption (CONAGUA 2012). In the Mexican state of Zacatecas, where semi-arid conditions prevail, groundwater is the only permanent water source; consequently groundwater flow delineation and precise mapping of different flow patterns is important for management and planning for different uses. Groundwater follows a complex recharge-discharge system, and its analysis is often the cause of great 
uncertainty due to the lack of data (Li et al., 2014), the behaviour of groundwater can be affected by multiple natural factors, such as chemical reactions between water and soil or sediments, biochemical reactions, the interaction between surface water and groundwater, as well as human activities (Zhang et al., 2014). In this context, hydrogeochemical studies were conceived as a tool to understand groundwater systems. Some of the most significant advances achieved in recent decades in this field are as follows: defining of mechanisms in chemical reactions through thermodynamic data evaluation; the improvement of analytical techniques for the measurement of a larger number of isotopes in small samples with low concentrations; and finally, the development of computational tools where numerical modelling techniques will undoubtedly provide better interpretations of systems and reactions in groundwater (Pierre and Plumer, 2012). Various of water-rock interactions mainly regulate the chemical composition of groundwater in aquifers. Examples of this include the following: ion exchanges, redox reactions, dissolution, carbonate precipitation and organic matter degradation (Vandernbohode and Lebbe, 2012). Groundwater chemical properties depend directly on different processes that occur in the subsoil (Kumar et al., 2011). Furthermore, groundwater is influenced by anthropogenic activities developed within the watersheds overlying aquifers. Various hydrogeochemical studies have been performed to identify geochemical processes and their relationship to water quality in aquifers (Fehdi et al., 2009; Horst et al., 2011; Rasaouli and Seyed, 2011).

The characterization of groundwater quality in regional groundwater bodies is necessary to determine the potential for groundwater development as well as to predict and control possible regional changes in groundwater quality due to groundwater abstraction or other external influences, such as large-scale irrigation or civil engineering work. Groundwater use may lead to conflicts of interests, such as from sewage and industrial waste products disposal, or agricultural needs which are capable of altering groundwater quality, and monitoring groundwater is an on-going need (Jousma, 2006; Gbadebo et al.; 2012). In this context, it is important to mention that the measurements of arsenic and fluoride become critical in the hydrochemical characterization of groundwater. The presence of total inorganic arsenic (As) and fluoride $\left(\mathrm{F}^{-}\right)$in groundwater has been observed frequently worldwide. A high concentration of As in water destine for human consumption usually causes health problems. Furthermore, the use of this water for irrigation could cause problems in crop production and in the food chain (Estrada-Capetillo et al., 2014). Although there are anthropogenic sources, such as the use of arsenical pesticides in agriculture and wood preservation, most large-scale groundwater occurrence have been documented as having geological origin. As from the reaction of oxidized of sulphide minerals in metasedimentary rocks, which have greater variability of arsenic, with averages and ranges somewhat higher than those of igneous and metamorphic rocks, mainly shale, with mean values of $28 \mathrm{ppm}$ in alluvial basins quaternary results in high concentrations in large areas (Apelo and Heederik, 2006). In the specific case of $\mathrm{F}^{-}$, adverse effects on human health from high $\mathrm{F}^{-}$concentrations have been revised by different researchers (Gómez et al., 2009, Subba 2006; Husthesain et al., 2012). The $\mathrm{F}^{-}$concentration values that are generally associated with regional flow systems are proportionate to the degree of water-rock interaction with fluorite $\left(\mathrm{CaF}_{2}\right)$ and with the residence times in aquifers (Sung, 2012) where the metamorphic rocks could have a fluorine concentration of 100 ppm (regional metamorphism) to more than $5000 \mathrm{ppm}$ (contact metamorphism) and where the original minerals are enriched with fluorine through metasomatic processes 
(Brunt et al., 2004). Other source of $\mathrm{F}^{-}$may include soil contamination from fertilizer and pesticide phosphate reaching the groundwater (Daessle' et al., 2009).

Authors have primarily used the Piper diagram to classify water in facies. This method describes the main characteristics of groundwater flow in aquifers; through this analysis, it is possible to define the processes that control increases or decreases of major ions concentrations such as: sodium $\left(\mathrm{Na}^{+}\right)$, potassium $\left(\mathrm{K}^{+}\right)$, magnesium $\left(\mathrm{Mg}^{2+}\right)$, calcium $\left(\mathrm{Ca}^{2+}\right)$, bicarbonate $\left(\mathrm{HCO}_{3}{ }^{-}\right)$, sulphate $\left(\mathrm{SO}_{4}{ }^{2-}\right)$, carbonate $\left(\mathrm{CO}_{3}{ }^{2-}\right)$, and chloride $\left(\mathrm{Cl}^{-}\right)$. These parameters permit characterization of the groundwater flow systems in aquifers, since discharge areas generally tend to exhibit higher concentrations than those in recharge areas due to the residence time and prolonged contact of water with the geologic structure of aquifers (Garfias et al., 2013; Andrade and Stigter, 2011; Atkinson 2011; Subba, 2011; Gibrilla et al., 2009). A Geographic Information System (GIS) can help in the hydrogeochemical characterization of water in aquifers. It facilitates, through mapping, the analysis of water resources and appropriate decision-making (Saidi 2011). A GIS is also a support tool in the definition of possible recharge areas and the quantification of surface water infiltration with the construction of thematic maps (Kumar et al., 2011; Tweed et al., 2007; Shomar et al., 2010; Ahmad et al., 2011). Furthermore, there are several geostatistical applications for estimating other environmental variables, with recent kriging applications used to evaluate the spatial distribution of groundwater quality parameters (Adhikary et al., 2012; Júnez-Ferreira and Herrera, 2013). Geostatistics have also been employed in the design of groundwater quality and hydraulic head monitoring networks (Herrera et al., 2004; Júnez-Ferreira et al., 2013).

To evaluate the groundwater quality and soil chemistry with an analysis of major and minor ions, and trace metals, multivariate methods have been used to understand hydrological factors such as aquifer boundaries, groundwater flow patterns and hydrochemical components (Uddamer et al., 2014; Kolsi et al., 2013).

In the specific case of principal component analysis (PCA), valuable information about the most significant parameters, which describe the whole data set, consisting of a large number of inter-related variables, are provided, thereby rendering data reduction with minimum loss of original information (Marghade et al., 2015).

The specific objectives in this paper were to identify flow patterns with the definition of hydrochemical facies and with the use of statistical techniques, to evaluate the geochemical evolution of As and $\mathrm{F}^{-}$, to verify the quality according to the norms of the World Health Organization (WHO) and recognize the potential recharge zone with the use of GIS, which combines maps of physicochemical parameters concentrations (generated with the use of geostatistics).

\section{Materials and methods}

\section{Study Area (SA)}

The National Water Commission (CONAGUA) took several factors into consideration (geopolitical boundaries, areas with high a volume of wells, and hydrological basins among others) to define 653 groundwater management units across the country, called Administrative Aquifer (AA). Thirty-four AA were proposed in the state of Zacatecas. Two of them are the Benito Juarez Aquifer (BJA) and the Calera Aquifer (CA), which are located in the central-southern region where crop irrigation and rain-fed agriculture are the main economic activities; they are only aquifer with a 
hydrogeology setting. The SA is located in the Sierra Madre Occidental volcanic terrain, which is within the southern part of a regional graven structure that has its origin in the Calera endorheic basin, which is characterized by ephemeral streams that are dry most of the year. The Zacatecas Mountain Range includes the Pilas Complex (maximum elevation 2,700 m a.s.1.) and the Jerez Mountain Range includes the Chilitas Formation with a flat area (2010 $\mathrm{m}$ a.s.1.) in the south-central portion and another flat area $(2100 \mathrm{~m}$ a.s.l.) in the north (Fig 1)

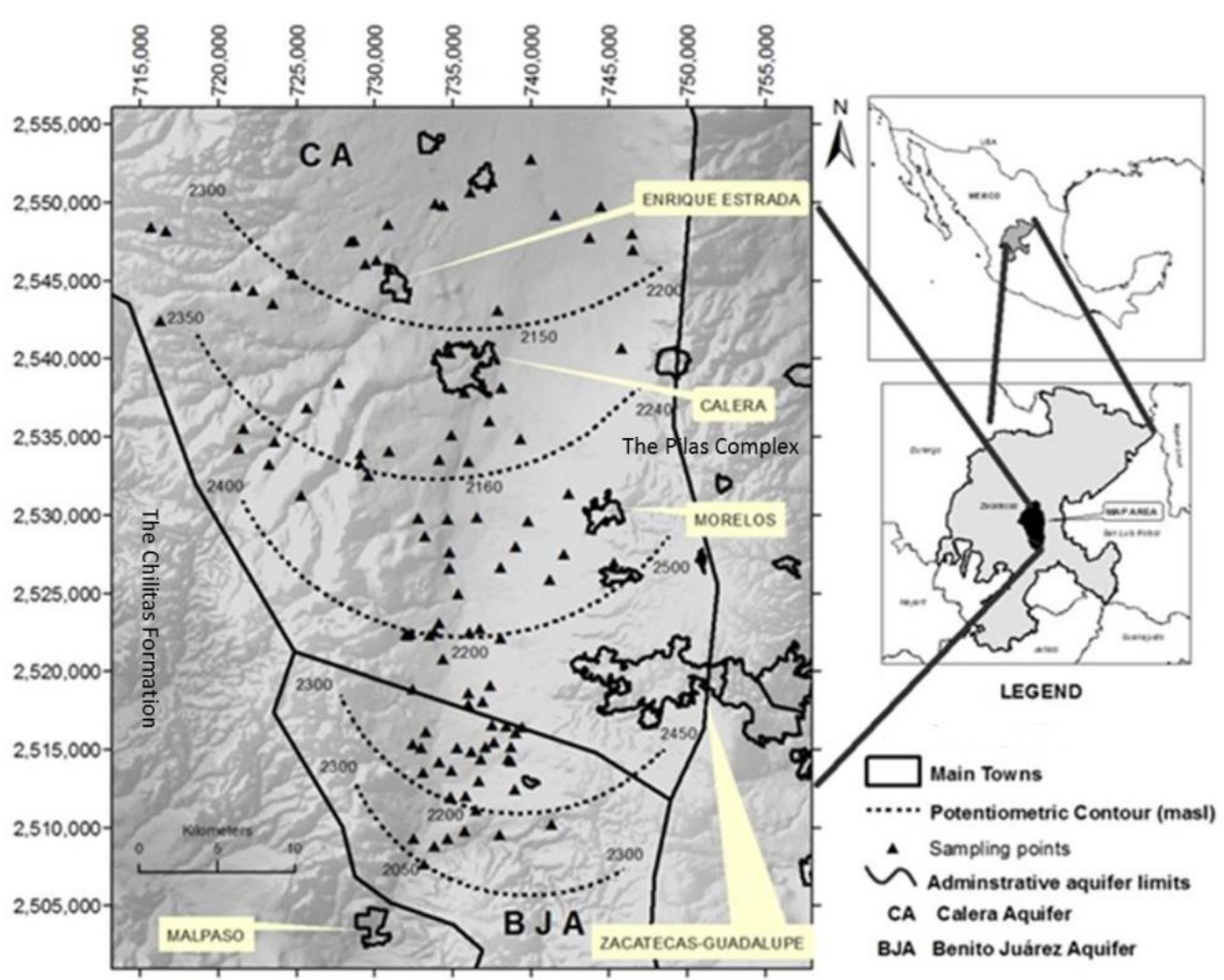

Figure 1. Location of study area (SA)

Additional significance includes the fact that $50 \%$ of the total drinking water that is supplied to Calera, Morelos, and Zacatecas-Guadalupe metropolitan area comes from these two AAs. Although several groundwater quality studies have been performed in the last twenty years, the delineation of groundwater flow patterns remains unknown. Administrative regulation constrains additional water extraction to the actual total volume $\left(23 \times 106 \mathrm{~m}^{3} /\right.$ year) and water use change from irrigation to human consumption should be taken into consideration.

This area is considered semiarid, and the annual rainfall average is less than the maximum potential annual evaporation. These regions are characterized by a scarcity of water, with highly erratic of rainfall distribution and a few torrential events. In this specific case, there is intensive agricultural activity, which depends on the extraction of groundwater. Commerce in the form of animal breeding is a complementary occupation in the Zacatecas-Guadalupe metropolitan area. On the other hand, in the last 30 years mining activity has gained strength and has begun to have an important influence on groundwater quality. With regards to industrial activity, there are only a few companies; however, two of 
them employ heavy extraction of groundwater. The climate is semi-arid with a rainy season in the summer and an annual average air temperature of $15.7^{\circ} \mathrm{C}$. The rainfall average (2006-2015) ranges from 416 to $493 \mathrm{~mm} /$ year with potential evaporation of up to 1990 $\mathrm{mm} /$ year, making irrigation essential for profitable agricultural activity. The climate data were obtained from three monitoring stations (U.A. Agronomia, CECAZ and Mesa de Fuentes) located within the SA (INIFAP 2015) (Fig 2).

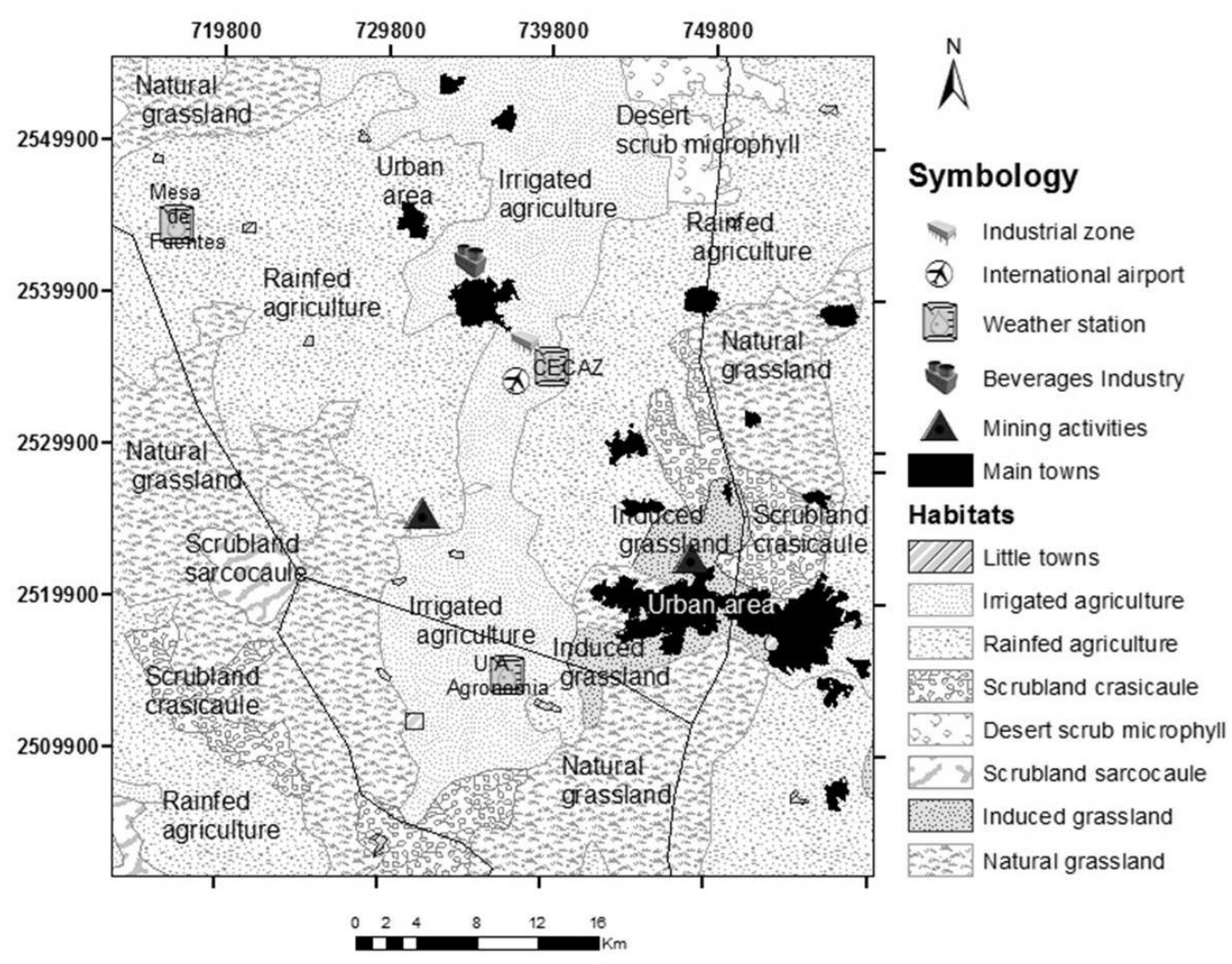

Figure 2. Habitats and surrounding

The plant species that predominate include desert scrub microphyll, which is distributed from 2050 to 2540 meters, of predominately "mesquite" and "opuntia" (prickly pear), among others. In the Sierra de Zacatecas we also identified characteristics specific to these elevations such as the presence of chamomile and cedar, which species occupy very small areas, indicating that these species are about to disappear. Natural grassland occupies nearly of $38 \%$ of the SA, dominated by a grass species called "zacaton" which is associated with thorn scrub. The agriculturally introduced vegetation (irrigated and rainfed) occupies approximately $50 \%$ of the SA and includes crops such as beans, peppers, fodder and vegetables.

The presence of different vegetative species is determined mainly by the type of climate, temperature and rainfall; these two factors cause a dry weather period during the initial months of the year and another that can be considered humid in the months of June, July, August and September, when the rainfed agriculture occurs; irrigated agriculture begins in the months of March-April and may not end until October (INIFAP 2015) (Fig 3). 


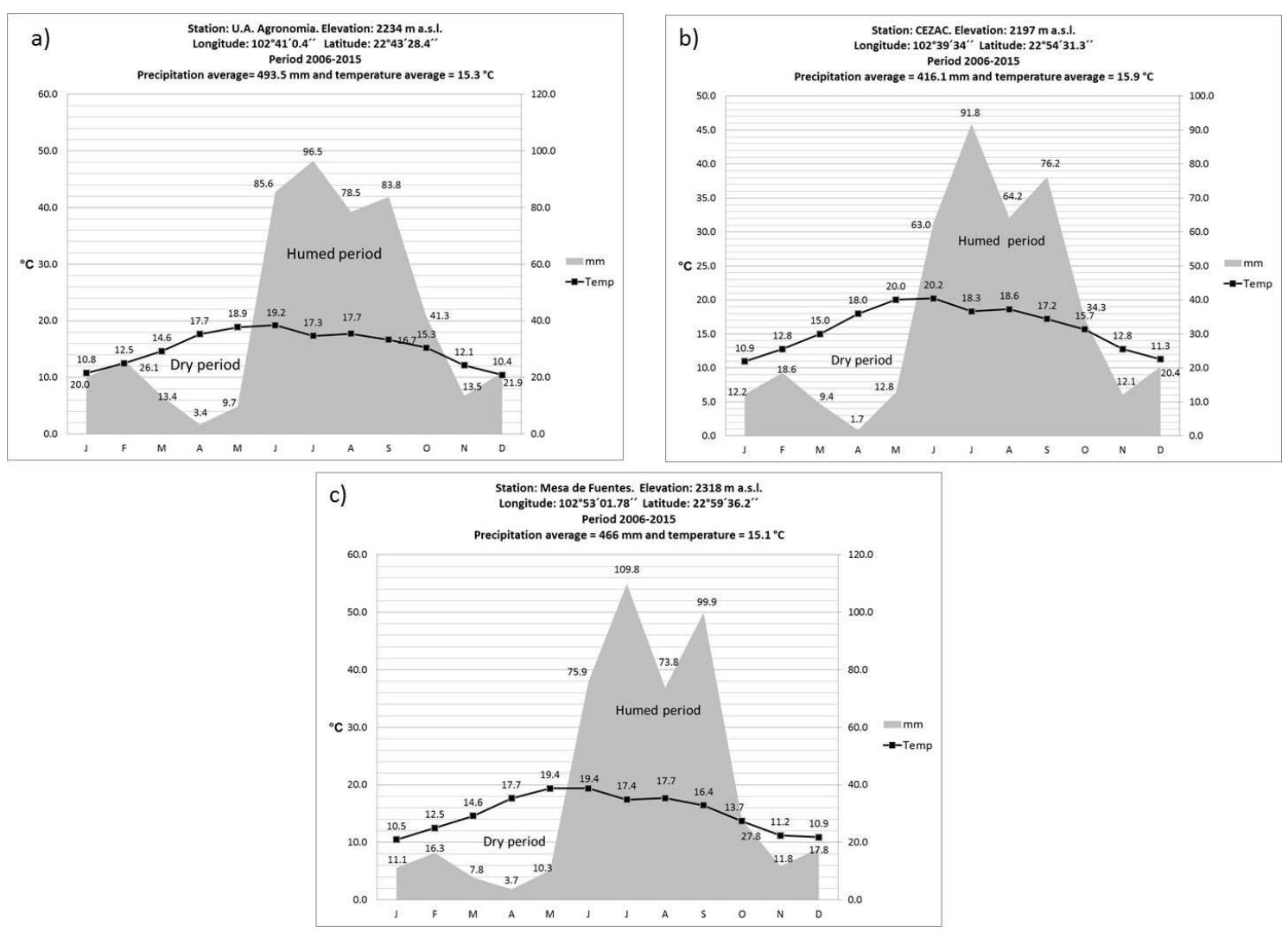

Figure 3. Climate diagram

\section{Geology and hydrogeology}

In the basin, two types of aquifers are recognized; one of them consists of limestone, conglomerates, and piedmont deposits, which results in poor groundwater movement; the other aquifer consists of filling materials deposited in the valley, which is more extensive and possesses greater potential for production wells under good transitivity. The SA is heterogeneously contained in the Basin Fill Sediments and the Tertiary Fractured Volcanic sediments, it is hydraulically continuous between the ABJ and AC, groundwater flows takes place from south to north, and the depth of the water table is from 40 to $135 \mathrm{~m}$ below the surface. The central part is formed by permeable Basin Fill Sediments (hydraulic conductivity ranging from 10-4- 10-5 m/s); hydraulic properties for Tertiary Fractured Volcanic units are unknown. Groundwater is in unconfined conditions, and the wells (90-250 m deep) have been identified mainly tapping the Basin Fill Sediments; the use of groundwater for irrigation is $68 \%$ and human consumption is $32 \%$ of the total extraction. Metamorphic rocks covering this system form the oldest unit; there is a sequence of sedimentary rocks and volcanic rocks interbedded. The principal geological features are shown based on a Mexican Geological Survey -SGM- (Fig 4).

The Calera horst-graven structure developed over a long stage during the Late Tertiary and Early Quaternary; the normal faults have three main trends: i) North-South; ii) Northwest-Southeast; and iii) Northeast-Southwest. They led the uplift of peripheral Tertiary volcanic mountains, central area settlements, and the deposition of basin fill sediments (alluvial material interbedded with tuffs) with a maximum thickness of 400 
$\mathrm{m}$, as indicated by geoelectric surveys. From the Late Tertiary, the mountains underwent a rapid uplift, the Tertiary Fractured Volcanic Unit is represented by the following: i) rhyolite lava flows with porphyritic texture with quartz, sanidine and plagioclase in a glassy matrix, biotite and clay as an accessory and secondary mineral; and ii) tuffs and ignimbrites with a felsic nature.

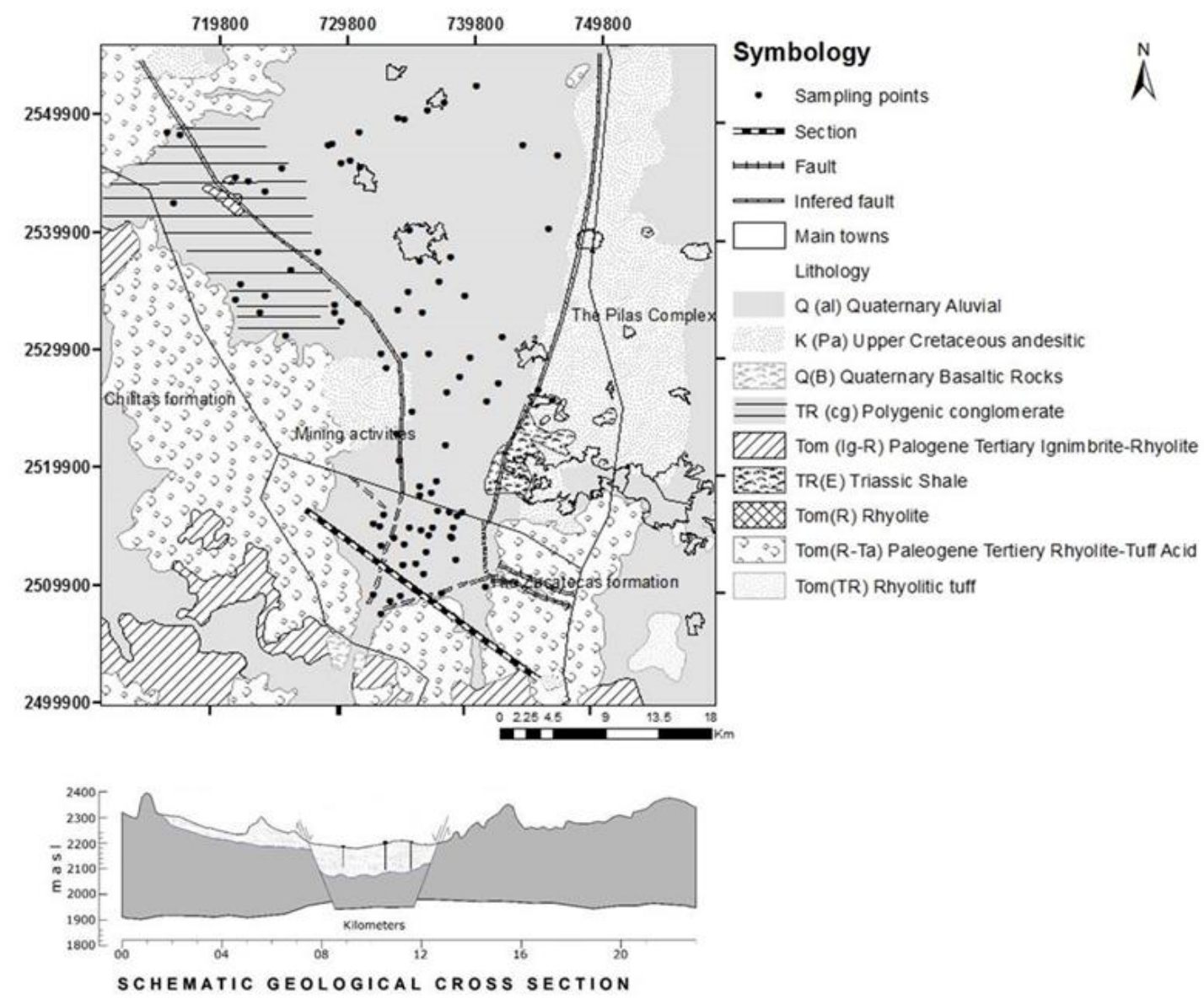

Figure 4. Geological map and cross section

Erosion from the mountains led to substantial transportation of clastic material into the basin, thick alluvial and Aeolian deposits led to Basin Fill Sediments, and the base layer is represented by a Chilitos Formation (Upper Jurassic, metabasaltic and metandesitic pillow lava flows, and volcano-sedimentary deposits), in the southwestern SA, the Zacatecas Formation (Upper Triassic, volcanoclastic low grade metamorphic rocks) in the southeastern SA, which is composed of feldspathic wacke, mudstone chert and discrete limestone lenses, accompanied by basaltic lava flows, rare dikes and hydrothermal vent-like structures, and in the Las Pilas Complex which is mainly composed of laccolithic intrusions and basaltic lava flows, interlayered with feldspathic and lithic wacke, mudstone chert and rare limestone; these units outcrop northeast of the SA, around Zacatecas City. In the case of the Las Pilas Complex, lava flows are comprised of plagioclase, clinopyroxene and rare quartz. Such as in the Zacatecas formation, the alteration developed chlorite, epidote, sericite and calcite, together with quartz and calcite 
veinlets. In the west, there is the Francisco I. Madero massive sulphide deposits developed in an island arc setting with intense mining activities, which evolved into the Las Pilas Complex (Escalona-Alcázar et al., 2014).

\section{Methodology}

A groundwater sampling campaign was conducted in 91 wells (March 2013 to October 2015). Knowing that the distribution of these wells in the study area is not homogeneous, seventy-two groundwater samples were taken from Basin Fill Sediments, while the others were taken from different geology formations of Tertiary Fractured Volcanic Units. Sixty-seven are used in agricultural activities and 24 are used for human consumption. The monitoring time period was a season of the year when extraction occurs for agricultural use. This is a complete way to analyse the behaviour of groundwater because the field conditions created a homogeneous sampling of the total area extent. In field analyses temperature (T), electrical conductivity (EC) and $\mathrm{pH}$ were included using an isolation cell to prevent atmospheric interaction before measurements were taken and improve electrode stability was ensured. The samples were filtered $(0.45 \mu \mathrm{m}$ membrane filters) and acidified $\left(1 \% \mathrm{v} / \mathrm{v} \mathrm{HNO}_{3}{ }^{-}\right)$in the field. Analytical determinations were carried out in the Environmental Engineering Laboratory of the Autonomous University of Zacatecas. The major ions $\mathrm{Ca}^{2+}, \mathrm{Na}^{+}, \mathrm{K}^{+}$and $\mathrm{Mg}^{2+}$ were analysed with atomic absorption spectrophotometry (Thermo Scientific ICE AA 3300). Chloride was determined by titration using an $\mathrm{AgNO}_{3}$ and $\mathrm{K}_{2} \mathrm{CrO}_{4}$ indicator. The other anions were determined using colorimetry, $\mathrm{SO}_{4}{ }^{2-}$ by precipitation of $\mathrm{BaSO}_{4}$, $\mathrm{N}_{-} \mathrm{NO}_{3}{ }^{-}$with an automated cadmium reduction method, and $\mathrm{F}^{-}$by the reaction between fluoride and a zirconium-dye lake. $\mathrm{SiO}_{2}$ was determined with the spectrophotometric method. Total alkalinity as $\mathrm{HCO}_{3}{ }^{-}$was determined by titration using $\mathrm{H}_{2} \mathrm{SO}_{4}$, phenolphthalein and bromophenol blue indicators. Only trace elements were analysed at Geology Institute of Autonomous University of San Luis Potosi with the same controls. Calibrations for atomic absorption spectrophotometry and automated colorimeter were performed using an appropriate dilution standard and both laboratory and international reference material were used as checks of accuracy (4 sigma). Additional control includes the ionic balance; the balance lay below $\pm 6 \%$. All of the determinations were conducted under the guidelines described in APHA-SMWW 2006 and applicable Mexican regulations as of 2015.

\section{Data analysis}

In the present study, the water quality parameters were analysed using Statistica7. The Pearson correlation coefficients were obtained, which are very useful for understanding the main hydrogeochemical processes in a groundwater system. Additionally, a PCA was performed to reduce the number of variables in a data set to a smaller number without the loss of essential information. This is a powerful technique that tries to explain the variance of a large set of intercorrelated variables and that transforms them into a smaller set of independent variables (uncorrelated). The number of components to retain in the PCA was determined by the Kaiser criterion for which only the components with Eigenvalues greater than one are retained ( $\mathrm{Li}$ et al., 2013). The geostatistical 
analysis was performed using kriging in the Geographic Information System ArcGIS 10.0; this may be considered an optimal geostatistical approach for interpolation at unsampled locations. It is flexible and it permits the investigation of spatial autocorrelation of the variables. One of the main advantages of kriging is that it presents a possibility to estimate the interpolation error of the values and the regionalised variable when there are not initial measurements (Adhikary et al., 2010). This tool is a local estimation technique that provides the best linear unbiased estimator of a studied unknown characteristic. Data analysis was complemented with the software AquaChem2014, which is a program, designed by Waterloo Hydrogeologic and contains a data base that is fully editable with an important set of data analysis tools for water quality. Specific functions contained in this program are; among others, the following: unit conversions, ionic balances, comparison and classification of samples, trend analysis and comparison with international standards. The integration of these tools allows for definition of a methodology to identify patterns of groundwater flow.

\section{Results and discussions}

The basic statistic for the chemical analysis and field measurements are shown in Table 1. Some parameters such as skewness (approximately 0) and kurtosis (03 ), and very similar results in the mean and median indicate a normal distribution for a sample population. These conditions, in the case of major ions suggest a normal distribution for $\mathrm{HCO}_{3}{ }^{-}, \mathrm{Ca}^{2+}$ and $\mathrm{K}^{+}$; this was not true for the other ions and trace elements. The dispersion of data reflects the heterogeneity of the SA.

Table 1. Basic statistic of sampling points

\begin{tabular}{|c|c|c|c|c|c|c|c|}
\hline Parameter & Min & Max & Med & Mean & St Deviation & Skewness & Kurtosis \\
\hline Temperature $(\mathrm{T}){ }^{\circ} \mathrm{C}$ & 18.7 & 34.1 & 25.5 & 25.65 & 2.74 & 0.07 & 0.99 \\
\hline pH & 6.5 & 8.79 & 7.5 & 7.5 & 0.432 & -0.60 & 0.92 \\
\hline EC & 120.0 & 1480 & 439.9 & 475.6 & 205.7 & 2.47 & 4.05 \\
\hline TDS & 49.6 & 1064 & 379.6 & 398.6 & 131.2 & 2.65 & 4.74 \\
\hline Alkalinity & 108.8 & 297.6 & 154.8 & 157.4 & 29.97 & 1.14 & 1.89 \\
\hline $\mathrm{HCO}_{3}^{-}$ & 132.7 & 363.1 & 189.2 & 192.4 & 36.54 & 1.11 & 1.88 \\
\hline $\mathrm{Cl}^{-}$ & 5.9 & 148.9 & 15.36 & 20.83 & 26.9 & 3.99 & 5.68 \\
\hline $\mathrm{SO}_{4}{ }^{2-}$ & 2.0 & 360 & 20.35 & 33.64 & 56.5 & 4.77 & 8.43 \\
\hline $\mathbf{F}^{-}$ & 0.4 & 2.2 & 0.868 & 0.949 & 0.411 & 1.03 & 1.05 \\
\hline $\mathrm{NO}_{3}{ }^{-}$ & 0.0 & 9.7 & 2.15 & 2.38 & 1.78 & 1.53 & 1.64 \\
\hline $\mathrm{Ca}^{2+}$ & 5.8 & 128.1 & 42 & 45.9 & 19.66 & 1.45 & 1.93 \\
\hline $\mathrm{Mg}^{2+}$ & 0.2 & 87.8 & 5.43 & 11.07 & 15.37 & 3.16 & 4.63 \\
\hline $\mathrm{Na}^{+}$ & 0.5 & 86.6 & 20.83 & 23.9 & 12.54 & 2.16 & 3.20 \\
\hline $\mathbf{K}^{+}$ & 1.4 & 17.95 & 6.38 & 7.06 & 2,905 & 0.50 & 1.10 \\
\hline $\mathrm{SiO}_{2}$ & 19.0 & 111 & 63.1 & 66.8 & 21.04 & -0.02 & 0.49 \\
\hline $\mathbf{T H}_{\left(\mathrm{CaCO}_{3}\right)}$ & 55.9 & 689.8 & 144.1 & 161.5 & 99.4 & 3.36 & 5.20 \\
\hline $\mathrm{Sr}$ & 0.012 & 0.819 & 0.142 & 0.2024 & 0.168 & 1.30 & 1.06 \\
\hline $\mathbf{L i}$ & 0.003 & 0.604 & 0.03766 & 0.0501 & 0.0637 & 7.46 & 21.30 \\
\hline As & 0.001 & 0.071 & 0.01024 & 0.0128 & 0.0094 & 3.07 & 5.78 \\
\hline
\end{tabular}

$\mathrm{EC}=$ Electrical Conductivity, TDS=Total dissolved solids and TH=Total hardness, all parameters in mg/L (Except pH and T) 
The mean value concentration $(\mathrm{mg} / \mathrm{L})$ of the representative dominant ions in the groundwater, in decreasing order, were as follows: $\mathrm{HCO}_{3}^{-}$(192.4), $\mathrm{Ca}^{2+}$ (45.9),

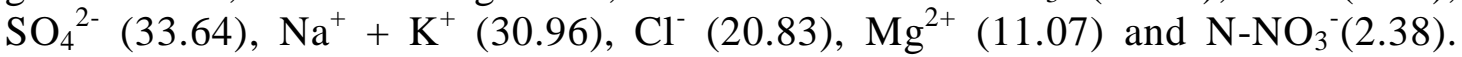
With the exception of fluoride $\left(\mathrm{F}^{-}\right)$and arsenic (As), the parameters analysed in this paper met the standard established by the WHO for human consumption. The As values ranged between 0.002 to $0.071 \mathrm{mg} / \mathrm{L}$, with 48 of the samples exceeding the drinking water guideline value of $0.010 \mathrm{mg} / \mathrm{L}$. Eleven of them are from wells that provide water for human consumption, there are not studies that provide information of the degree of damage to health from using this groundwater. Values above $0.010 \mathrm{mg} / \mathrm{L}$ in the east were mainly related to mining activities where the presence of sulphide was present; it can be commonly found in the form of arsenopyrite (AsFeS). However, other areas with high natural concentrations are associated with only the mineral components of the geological framework in the north, where the quaternary alluvial layer is present (Apelo, 2006) (Fig 5).

In the case of $\mathrm{F}^{-}$, the WHO established a maximum permissible value at 1.5 $\mathrm{mg} / \mathrm{L}$. This value was exceeded in eight wells with a maximum of $2.20 \mathrm{mg} / \mathrm{L}$. Two of these wells provide water for human consumption. While there is no evidence of health problems, there are specifically yellow spots in the teeth of the population using this water. Values above the permissible limit have occurred in the south, where there is intense agricultural activity and the use of phosphate pesticide is common practice; this situation has been occurring for the last three decades. The other zone is the northwestern area, where water with sodium characteristics exists, which is causing these values of $\mathrm{F}^{-}$, as has been reported in scientific literature (Brunt et al., 2004; Carrillo-Rivera et al., 2002) (Fig 6).

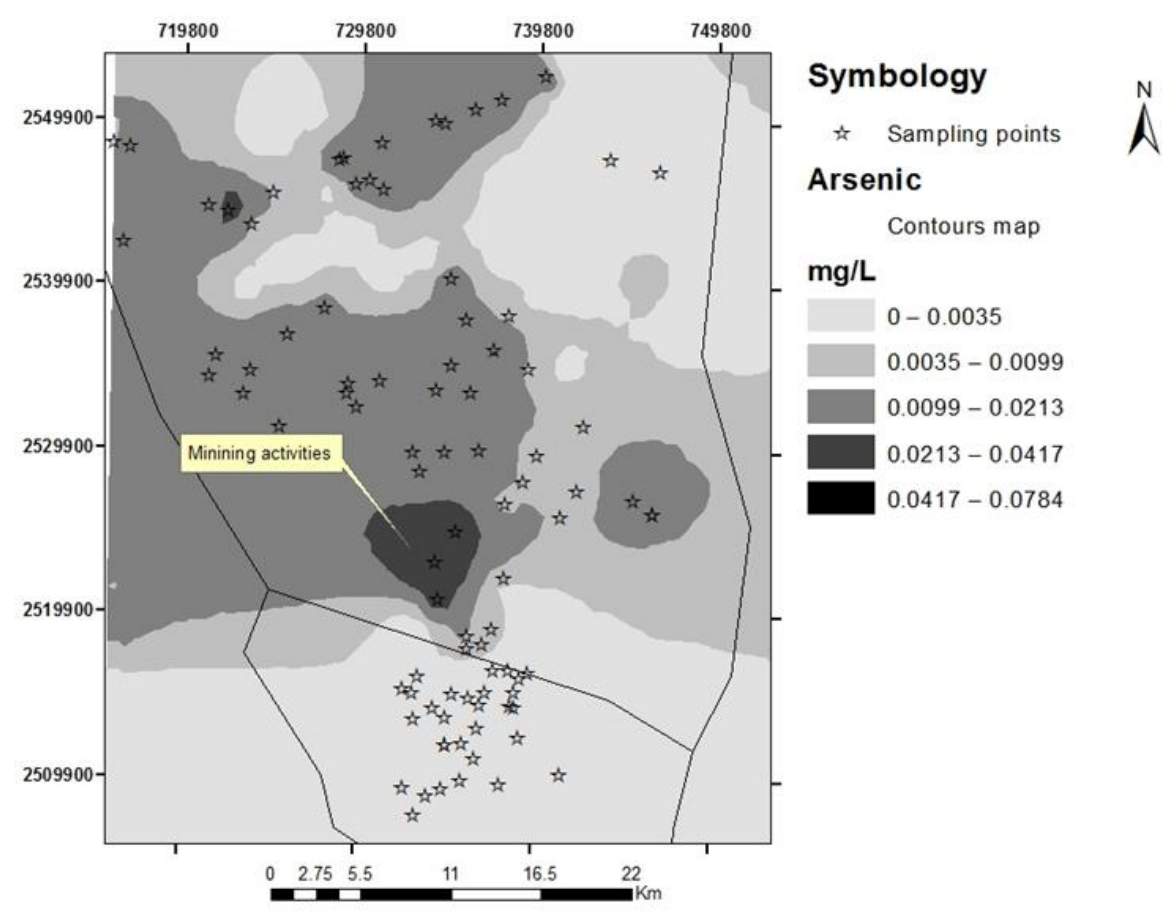

Figure 5. Contours map of Arsenic (As) 


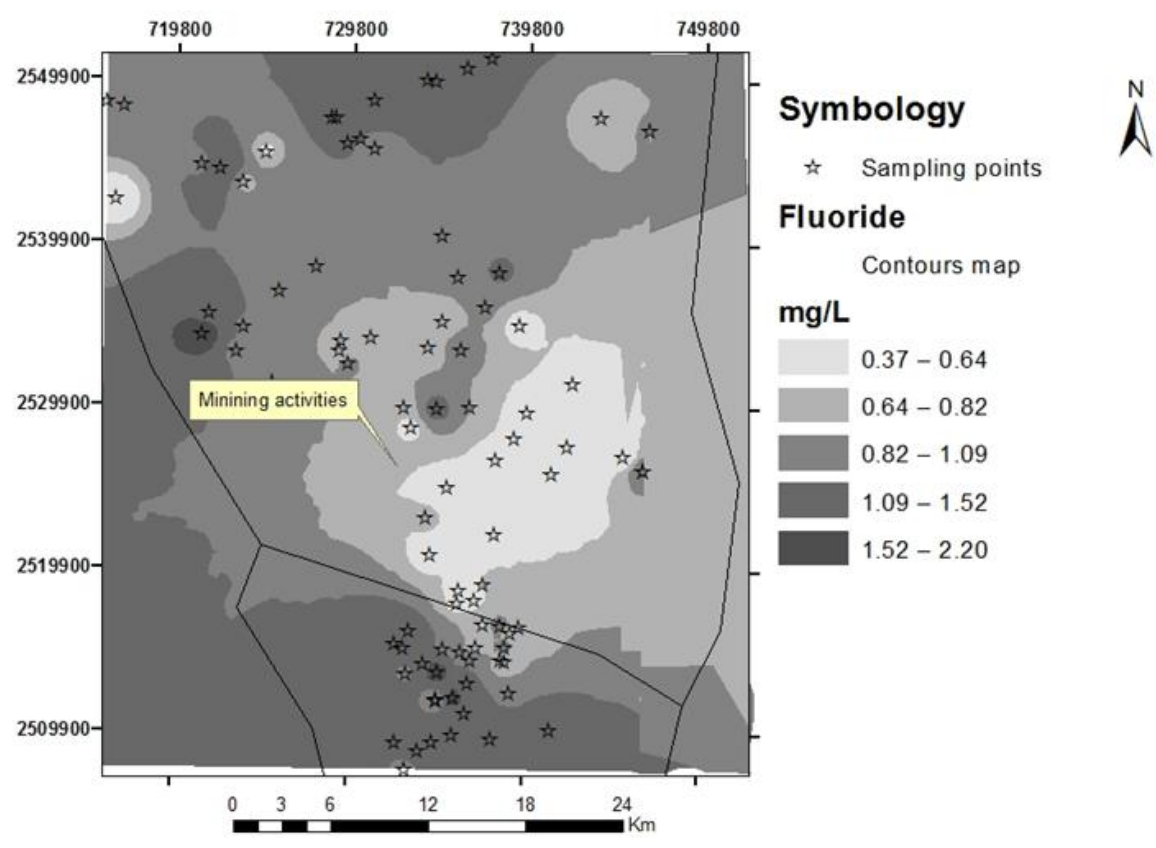

Figure 6. Contours map of Fluoride $\left(F^{-}\right)$

On the other hand, the Food and Agriculture Organization (FAO 2013) describes different characteristics to classify irrigation water. Basically, three criteria were considered: the salinity, sodicity and toxicity of specific ions. Two of the most important parameters to determine water quality for irrigation are the electrical conductivity (EC) and the Sodium Adsorption Ratio (SAR) index. With these a classification of water for irrigation following the norms of the U.S. was created at The Salinity Laboratory. The average value was $540 \mu \mathrm{S} / \mathrm{cm}$ for EC. Therefore, it is considered low in salts. The SAR can be related to the salinity levels (as EC) to evaluate possible problems of irrigation water. According to Figure 7, agricultural productivity in the SA is not affected by using water for irrigation (Rhodes et al., 1992).

Another parameter that is useful for measure the quality of water for domestic, irrigation, and industrial uses is the total hardness. Public acceptability of the degree of water hardness may vary considerably from one community to another. The threshold for calcium ions is in the range of $100-300 \mathrm{mg} / \mathrm{l}$, depending on the associated anion, and the taste threshold for magnesium is probably lower than that for calcium. Hardness levels between 80 and $100 \mathrm{mg} / \mathrm{L}$ (as $\mathrm{CaCO}_{3}$ ) are generally acceptable in drinking water and are considered tolerable by the consumer. In some instances, consumers tolerate water hardness in excess of $500 \mathrm{mg} / \mathrm{l}$ (Sappa et al., 2013). According to the USEnvironmental Protection Agency (EPA), water that contains $0-75 \mathrm{mg} / \mathrm{L} \mathrm{CaCO} \mathrm{Ca}_{3}$ is classified as soft, $75-150 \mathrm{mg} / \mathrm{L}$ as moderately hard, $150-300 \mathrm{mg} / \mathrm{L}$ as hard and $>300$ $\mathrm{mg} / \mathrm{L}$ as very hard. For SA the values obtained manifests characteristic from soft to moderately hard, with a maximum value corresponding to a shallow extraction point (6 m). This was localized in the Las Pilas Complex, which is in the east. These results indicate that the groundwater does not have problems of total hardness. 


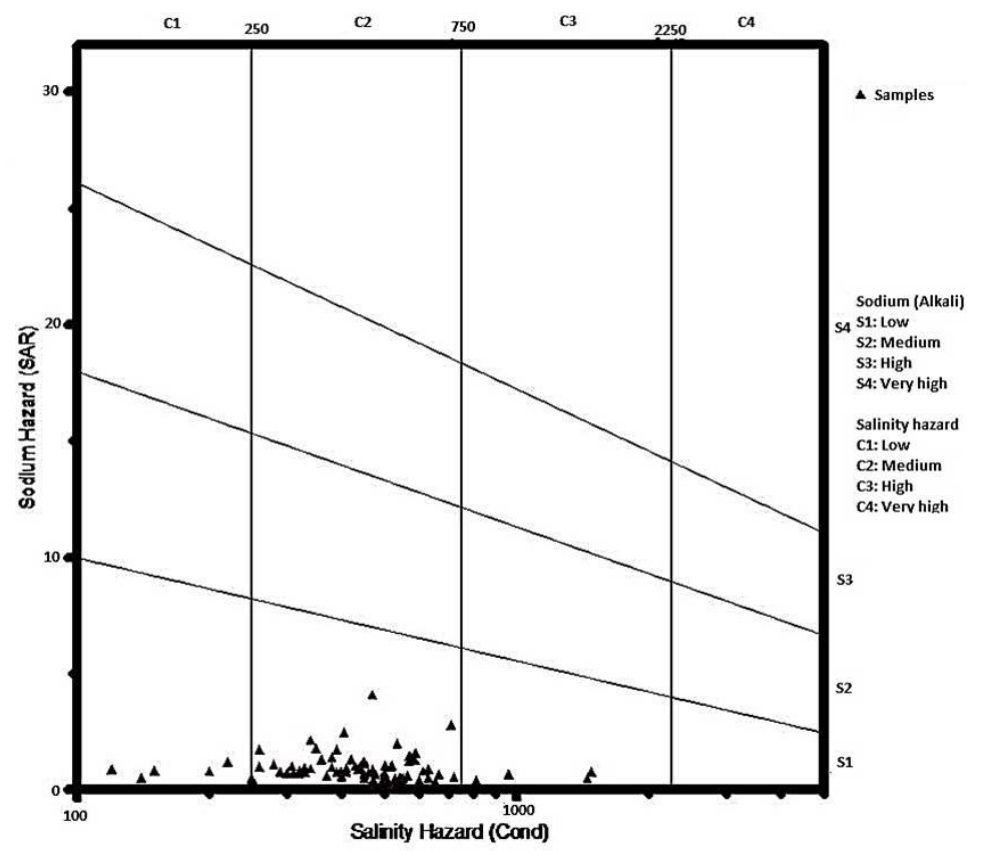

Figure 7. Classification of irrigation water of the $S A$

\section{Hydrogeochemical characterization}

In general, an increase in the concentrations of major ions with different patterns has been observed. In the particular case of $\mathrm{Cl}^{-}$(with mean of $15.36 \mathrm{mg} / \mathrm{L}$ ) it may have two different origins. One from atmospheric inputs (rain has a $\mathrm{Cl}^{-}$concentration less than 5 $\mathrm{mg} / \mathrm{L})$ in the southern region where the groundwater $\mathrm{Cl}^{-}$concentration is less than 8 $\mathrm{mg} / \mathrm{L}$ indicating a possible recharge zone (Veyna, 2014) The other was from an internal source derived from the movement of groundwater from south to northeast through the basin fill sediments. The higher value in the shallow extraction point $(6 \mathrm{~m})$ in the east $(148.9 \mathrm{mg} / \mathrm{L})$ could represent a discharge zone. The same singularities occurred for $\mathrm{SO}_{4}{ }^{2-}$ (ranges from 2 to $360 \mathrm{mg} / \mathrm{L}$ ) with a higher value in the same zone of the $\mathrm{SA}$. It is the result of the interaction of groundwater with sedimentary rocks and massive sulphide deposits present in the western part of the SA. It also reflects the movement of groundwater from west to east in the central part of the SA. For the ions, $\mathrm{Ca}^{2+} \mathrm{Mg}^{2+}$ and $\mathrm{K}^{+}$concentrations could be related to alterations of silicate. These alterations probably result from the disruption of biotite and the presence of pyroxenes originating from calcium with the release of $\mathrm{HCO}_{3}{ }^{-}$during silica hydrolysis. The minimum values are found in the south and the west of the SA, and the maximum values are located in the central and northeast zones. Silica concentrations occur almost entirely from the alteration of plagioclase and from some of the feldspars, which are associated with a considerable volume of rhyolite rocks in this area. However, often the dissolved silica is expressed as $\mathrm{SiO}_{2}$, in most natural waters it appears as $\mathrm{H}_{4} \mathrm{SiO}_{4}$. The $\mathrm{Na}^{+}$, which has a highest value of $86.6 \mathrm{mg} / \mathrm{L}$, comes from altering plagioclase, principally albite, which is located in the northwest of the SA and possibly belongs to a different flow system. These chemicals process are exemplified in the follows reactions:

a) $2 \mathrm{CaMgSi}_{2} \mathrm{O}_{6 \text { pyroxene }}+4 \mathrm{H}^{+}+2 \mathrm{H}_{2} \mathrm{O} \rightarrow 2 \mathrm{Ca}^{2+}+2 \mathrm{Mg}^{2+}+2 \mathrm{H}_{4} \mathrm{SiO}_{4}$ 
b) $2 \mathrm{KMg}_{3}\left(\mathrm{AlSi}_{3} \mathrm{O}_{10}\right)(\mathrm{OH})_{2 \text { biotite }}+14 \mathrm{H}^{+}+\mathrm{H}_{2} \mathrm{O} \rightarrow 2 \mathrm{~K}^{+}+6 \mathrm{Mg}^{2+}+4 \mathrm{H}_{4} \mathrm{SiO}_{4}+\mathrm{Al}_{2} \mathrm{Si}_{2} \mathrm{O}_{5}(\mathrm{OH})_{4 \text { Kaolinite }}$

c) $2 \mathrm{NaAlSi}_{3} \mathrm{O}_{8}$ albite $+9 \mathrm{H}_{2} \mathrm{O}+2 \mathrm{H}_{2} \mathrm{CO}_{3} \rightarrow 2 \mathrm{Na}^{+}+2 \mathrm{HCO}_{3}{ }^{-}+\mathrm{Al}_{2} \mathrm{Si}_{2} \mathrm{O}_{5}(\mathrm{OH})_{4 \text { Kaolinite }}+4 \mathrm{H}_{4} \mathrm{SiO}_{4}$.

The values of $\mathrm{N}^{-\mathrm{NO}_{3}}{ }^{-}$concentration reflect the effects of agrochemicals used in irrigation activities; concentrations are under a maximum permissible level for human consumption $(10 \mathrm{mg} / \mathrm{L})$. The different major ions proportions (in meq/L) in the groundwater and their evolution in the different geology settings of the SA are described by the Piper diagram (Fig 8). Groundwater chemical composition is classified in four hydrochemical faces. In the south, it is mainly $\mathrm{Ca}^{2+}-\mathrm{HCO}_{3}{ }^{-}$, the predominance of this face reflects infiltration of water in the fractured volcanic rocks that subsequently flows through the alluvial medium with interbedded limestone (granular undifferentiated); these results suggest low residence times. In the central part of the $\mathrm{SA}$, there is an evolution from $\mathrm{Mg}^{2+}-\mathrm{Ca}^{2+}-\mathrm{HCO}_{3}{ }^{-}$to $\mathrm{Mg}^{2+}-\mathrm{Ca}^{2+}-\mathrm{SO}_{4}{ }^{2-}$; these phenomena are associated with the transition from acid rhyolite-tuff to andesitic; they may reflect the presence of a flow pattern with more residence times. In the northward direction, there are $\mathrm{Ca}^{2+}-\mathrm{Na}^{+}-\mathrm{HCO}_{3}{ }^{-}$to $\mathrm{Ca}^{2+}-\mathrm{Mg}^{2+}-\mathrm{HCO}_{3}{ }^{-}$and $\mathrm{Na}^{+}-\mathrm{HCO}_{3}-$ to $\mathrm{Na}^{+}-\mathrm{Ca}^{2+}-\mathrm{HCO}_{3}{ }^{-}$ evolutions, indicating a Triassic conglomerate to alluvial transition. Apparently the last two evolutions are communicated in the northeastern part of the SA, suggesting a lengthy and deep flow circulation.

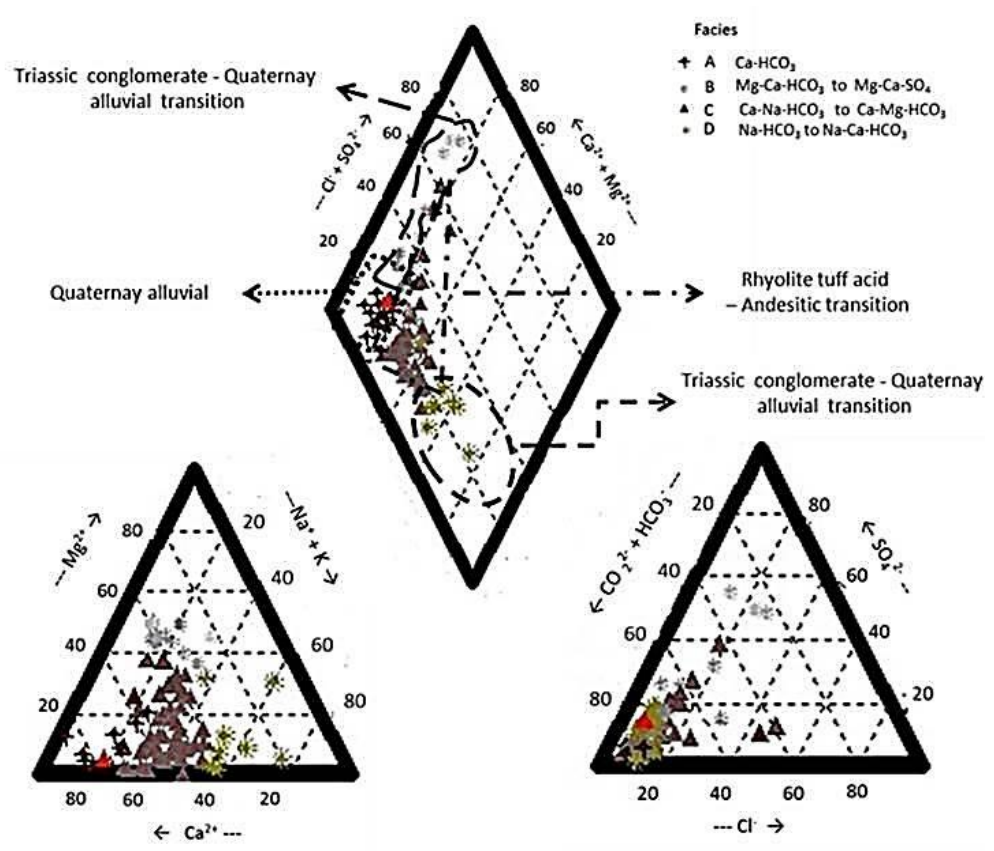

Figure 8. Trilinear diagram of samples (Piper)

\section{Correlation of parameters}

The statistical relationship between two or more variables may represent a correlation matrix. This tool can help in analysing the primary reactions that have been carried out in the water chemistry analysis (Li et al., 2013). The Pearson's correlation coefficients were calculated with the exclusion of temperature and alkalinity using Aquachem2014. The results are presented in Table 2. 
Table 2. Correlation parameters

\begin{tabular}{|c|c|c|c|c|c|c|c|c|c|c|c|c|c|c|c|c|c|}
\hline & $\mathbf{p H}$ & EC & TDS & $\mathrm{Ca}^{2+}$ & $\mathbf{M g}^{2+}$ & $\mathrm{Na}^{+}$ & $\mathbf{K}^{+}$ & $\mathrm{Cl}^{-}$ & $\mathrm{HCO}_{3}^{-}$ & $\mathrm{SO}_{4}{ }^{2-}$ & $\mathbf{F}^{-}$ & $\mathrm{N}-\mathrm{NO}_{3}{ }^{-}$ & As & $\mathbf{L i}$ & TH & $\mathrm{SiO}_{2}$ & $\mathrm{Sr}$ \\
\hline pH & 1 & -0.090 & -0.161 & -0.168 & -0.344 & 0.036 & 0.125 & -0.264 & -0.136 & -0.239 & 0.247 & -0.007 & -0.210 & -0.132 & -0.378 & 0.324 & -0.581 \\
\hline EC & & 1 & $\underline{0.824}$ & $\underline{0.765}$ & 0.657 & 0.203 & 0.069 & $\underline{0.717}$ & 0.438 & $\underline{0.770}$ & 0.025 & 0.314 & -0.096 & 0.082 & $\underline{0.794}$ & 0.023 & 0.292 \\
\hline TDS & & & 1 & $\underline{0.742}$ & $\underline{0.706}$ & 0.309 & 0.114 & $\underline{0.739}$ & 0.548 & $\underline{0.802}$ & -0.030 & 0.314 & -0.046 & 0.153 & $\underline{0.775}$ & 0.017 & 0.352 \\
\hline $\mathrm{Ca}^{2+}$ & & & & 1 & 0.439 & -0.105 & -0.083 & 0.612 & 0.456 & 0.587 & 0.032 & 0.093 & -0.163 & -0.061 & $\underline{0.757}$ & 0.098 & 0.160 \\
\hline $\mathbf{M g}^{2+}$ & & & & & 1 & 0.115 & -0.036 & $\underline{0.757}$ & 0.160 & $\underline{0.890}$ & -0.341 & 0.474 & -0.013 & 0.005 & $\underline{0.872}$ & -0.363 & 0.603 \\
\hline $\mathrm{Na}^{+}$ & & & & & & 1 & 0.364 & 0.163 & 0.353 & 0.198 & 0.296 & 0.200 & 0.337 & 0.634 & 0.028 & -0.115 & 0.217 \\
\hline $\mathbf{K}^{+}$ & & & & & & & 1 & 0.046 & 0.086 & 0.019 & 0.186 & 0.203 & 0.262 & 0.153 & -0.052 & 0.146 & 0.147 \\
\hline $\mathrm{Cl}^{-}$ & & & & & & & & 1 & 0.202 & $\underline{0.697}$ & -0.205 & 0.375 & 0.044 & 0.041 & $\underline{\mathbf{0 . 7 9 5}}$ & -0.181 & 0.555 \\
\hline $\mathrm{HCO}_{3}^{-}$ & & & & & & & & & 1 & 0.169 & 0.212 & -0.096 & -0.040 & 0.422 & 0.322 & 0.145 & 0.167 \\
\hline $\mathbf{S O}_{4}^{2-}$ & & & & & & & & & & 1.000 & -0.182 & 0.493 & -0.019 & -0.006 & $\underline{0.871}$ & -0.217 & 0.424 \\
\hline $\mathbf{F}^{-}$ & & & & & & & & & & & 1 & -0.005 & 0.057 & 0.307 & -0.174 & 0.150 & -0.297 \\
\hline $\mathrm{N}-\mathrm{NO}_{3}{ }_{3}^{-}$ & & & & & & & & & & & & 1 & 0.207 & 0.049 & 0.358 & -0.098 & 0.215 \\
\hline As & & & & & & & & & & & & & 1 & 0.488 & -0.054 & -0.250 & 0.354 \\
\hline $\mathbf{L i}$ & & & & & & & & & & & & & & 1 & -0.017 & -0.236 & 0.320 \\
\hline TH & & & & & & & & & & & & & & & 1 & -0.224 & 0.529 \\
\hline $\mathrm{SiO}_{2}$ & & & & & & & & & & & & & & & & 1 & -0.407 \\
\hline $\mathbf{S r}$ & & & & & & & & & & & & & & & & & 1 \\
\hline
\end{tabular}

Bold and underlined indicate correlation is significant at the 0.01 level (2-tailed), only bold indicate correlation is significant at the 0.05 level (2-tailed) 
Some characteristics were observed: i) TDS were strongly correlated with all major ions (> 0.700), except $\mathrm{HCO}_{3}^{-}(0.548)$ and $\mathrm{Na}^{+}(0.349)$, which indicate the constant accumulation of these ions in groundwater flow; ii) $\mathrm{HCO}_{3}{ }^{-}$had correlation coefficients less than 0.500 with $\mathrm{Ca}^{2+}$ and $\mathrm{Mg}^{2+}$, which suggests low dissolution and/or precipitation of calcite and dolomite; it is reasonable to mention that these minerals are not the principal sources of these ion; iii) $\mathrm{TH}$ was not correlated with $\mathrm{HCO}_{3}{ }^{-}$indicating permanent hardness; iv) the correlation coefficient of $\mathrm{Na}^{+}-\mathrm{Li}(0.643)$ was indicative of a possible separate flow pattern within the groundwater movement, and the low correlation coefficient $\mathrm{Na}^{+}-\mathrm{Cl}^{-}(0.163)$ revealed the poor influence of halite dissolution in the groundwater chemistry; v) the correlation coefficients of $\mathrm{Cl}^{-}-\mathrm{Ca}^{2+}(0.612)$ and $\mathrm{Cl}^{-}$ - $\mathrm{Mg}^{2+}(0.757)$ could be explained with cation exchange; vi) the correlation coefficients of $\mathrm{SO}_{4}{ }^{2-}-\mathrm{Ca}^{2+}(0.587)$ and $\mathrm{SO}_{4}{ }^{2-}-\mathrm{Mg}{ }^{2+}(0.890)$ could be interpreted as possible dissolution of gypsum and dolomite; therefore, silicates hydrolysis and cation exchange in the presence of sulphide deposit were the main chemical reactions in the groundwater of the $\mathrm{SA}$; and vi) the case of $\mathrm{F}^{-}$, As and $\mathrm{N}^{-} \mathrm{NO}_{3}{ }^{-}$indicated no correlation, denoting continuous motion in different stage within the SA.

\section{Principal Components Analysis (PCA)}

The results of the PCA are shown in Table 3. To reduce the similarity of the original variable; a varimax rotation was carried out. This is a way to understand the participation of the original variables more clearly (Elangbam et al., 2013). These results indicate that four principal components or variable factors (VF) had eigenvalues greater than 1 and represented $70.724 \%$ of the total variance.

Table 3. Principal Components Analysis (PCA)

\begin{tabular}{|c|c|c|c|c|}
\hline Variable & Factor 1 & Factor 2 & Factor 3 & Factor 4 \\
\hline pH & -0.150 & 0.017 & 0.777 & -0.169 \\
\hline Temperature ${ }^{\circ} \mathrm{C}$ & -0.267 & 0.427 & -0.248 & -0.423 \\
\hline $\mathrm{EC}(\mu \mathrm{S} / \mathrm{cm})$ & 0.823 & 0.093 & 0.089 & 0.406 \\
\hline $\mathrm{HCO}_{3}^{-}$ & 0.159 & 0.392 & -0.029 & 0.789 \\
\hline $\mathrm{Cl}^{-}$ & 0.841 & 0.013 & -0.199 & 0.155 \\
\hline $\mathrm{SO}_{4}{ }^{2-}$ & 0.913 & 0.022 & -0.126 & 0.033 \\
\hline $\mathrm{N}-\mathrm{NO}_{3}{ }^{-}$ & 0.640 & 0.169 & 0.154 & -0.462 \\
\hline $\mathbf{F}^{-}$ & -0.196 & 0.512 & 0.444 & 0.221 \\
\hline $\mathrm{Ca}^{2+}$ & 0.620 & -0.163 & 0.051 & 0.631 \\
\hline $\mathrm{Mg}^{2+}$ & 0.875 & -0.024 & -0.352 & -0.042 \\
\hline $\mathrm{Na}^{+}$ & 0.164 & 0.861 & 0.028 & -0.011 \\
\hline $\mathbf{K}^{+}$ & 0.148 & 0.478 & 0.339 & -0.164 \\
\hline $\mathrm{SiO}_{2}$ & -0.136 & -0.160 & 0.658 & 0.313 \\
\hline $\mathrm{Sr}$ & 0.464 & 0.240 & -0.669 & -0.009 \\
\hline $\mathbf{L i}$ & -0.060 & 0.829 & -0.265 & 0.180 \\
\hline Eigenvalues & 4.696 & 2.377 & 2.127 & 1.408 \\
\hline$\%$ Total variance & 31.309 & 15.850 & 14.178 & 9.388 \\
\hline Cumulative $\%$ Variance & 31.309 & 47.159 & 61.336 & 70.724 \\
\hline
\end{tabular}

Significant variable per each component (factorial loadings > 0.500)

The VF1 explained $31.309 \%$ of the variance; it was characterized by positive loading in $\mathrm{EC}, \mathrm{Cl}^{-}, \mathrm{SO}_{4}{ }^{2-}, \mathrm{N}_{-} \mathrm{NO}_{3}{ }^{-}, \mathrm{Ca}^{2+}$ and $\mathrm{Mg}^{2+}$, which represented the ion exchange and the weathering of silicates minerals across the basin fill sediments, as suggested by geochemical interpretation. It is important to mention that the influence of this factor in the groundwater chemistry occurs primarily in the SA. 
In VF2, the identified parameters were $\mathrm{F}^{-}, \mathrm{Na}^{+}$and $\mathrm{Li}$, exhibiting $15.850 \%$ of the variance; this factor was interpreted as an independent flow pattern, where the groundwater is in contact with rocks in the west of the SA with more relative movement time, probably, as part of a regional flow system towards the northeast that goes beyond the study area. Something important to mention about VF2 is the behaviour of the temperature correlation (0.427); although this parameter did not reach factorial loadings $(0.500)$, it may be related to the possible regional flow mentioned above.

VF3 contains $14.178 \%$ of the variance; it includes the $\mathrm{pH}$ and $\mathrm{SiO}_{2}$, with a negative influence from Sr. In the case of VF4, only the $\mathrm{HCO}_{3}{ }^{-}$is a parameter with influence, indicating the process of silicate hydrolysis.

\section{Determination of potential recharge-discharge areas}

The parameters in the SA were estimated by ordinary kriging. This allowed the estimation of values in positions of interest from a linear combination of the measured values represented by spatial autocorrelations and provided information about the spatial structure of a regionalized variable. For the development of ordinary kriging equations, a linear, unbiased and minimum variance-estimation was imposed. The maps of the spatial distribution of the analysed parameters were obtained for a regular grid formed by nodes, which were separated $50 \mathrm{~m}$ in both the North-South and East-West directions. Interpolation of water level data measured at some wells suggests a west-northeast preferential flow; however, through this type of analysis, it is not possible to distinguish some important features, such as separate flows that could be converging within the SA. It is known that groundwater geochemistry evolution is useful for identifying flow patterns and potential recharge zones. In this assessment, the results are discussed in relation to the Chebotarev sequence that describes the geochemistry of water evolution from recharge zones to discharge zones $\left(\mathrm{HCO}_{3}^{-}-\mathrm{SO}_{4}{ }^{2}-\mathrm{Cl}^{-}\right)$ (Chebotarev 1955). The Chebotarev sequence analysis suggests a south-northeast flow pattern, with relatively low residence time (sequence A), also a second flow pattern of west-east direction with a larger relative residence time (sequence B) where sulphate has substituted bicarbonate in the Chebotarev sequence. This analysis demonstrated additional evidence of a flows mixture with an interconnection to two different hydrochemical faces at the central part of the aquifer that converge in this zone with groundwater moving to the northeast (Sequence C) (Fig 9).

The values of $\mathrm{SO}_{4}{ }^{2-}$ and $\mathrm{Cl}^{-}$in Sequence $\mathrm{B}$ are predominantly larger than for those for Sequence A and C, this helped to identify different flow patterns as proposed in the analysis of the geostatistical results (Fig 10). The conceptual flow patterns definition agrees with an increase of parameters concentrations from south to northeast and west to northeast, except for nitrate-nitrogen for which the highest values were found in the south, as explained above. It is clear that when considering only water level data, the definition of different flows converging in north within the SA could be missed. The information provided by the Chebotarev sequence analysis and the presence of geological faults suggest that an important local recharge may be occurring in the western piedmont and conditions of discharge in the east of the SA. 


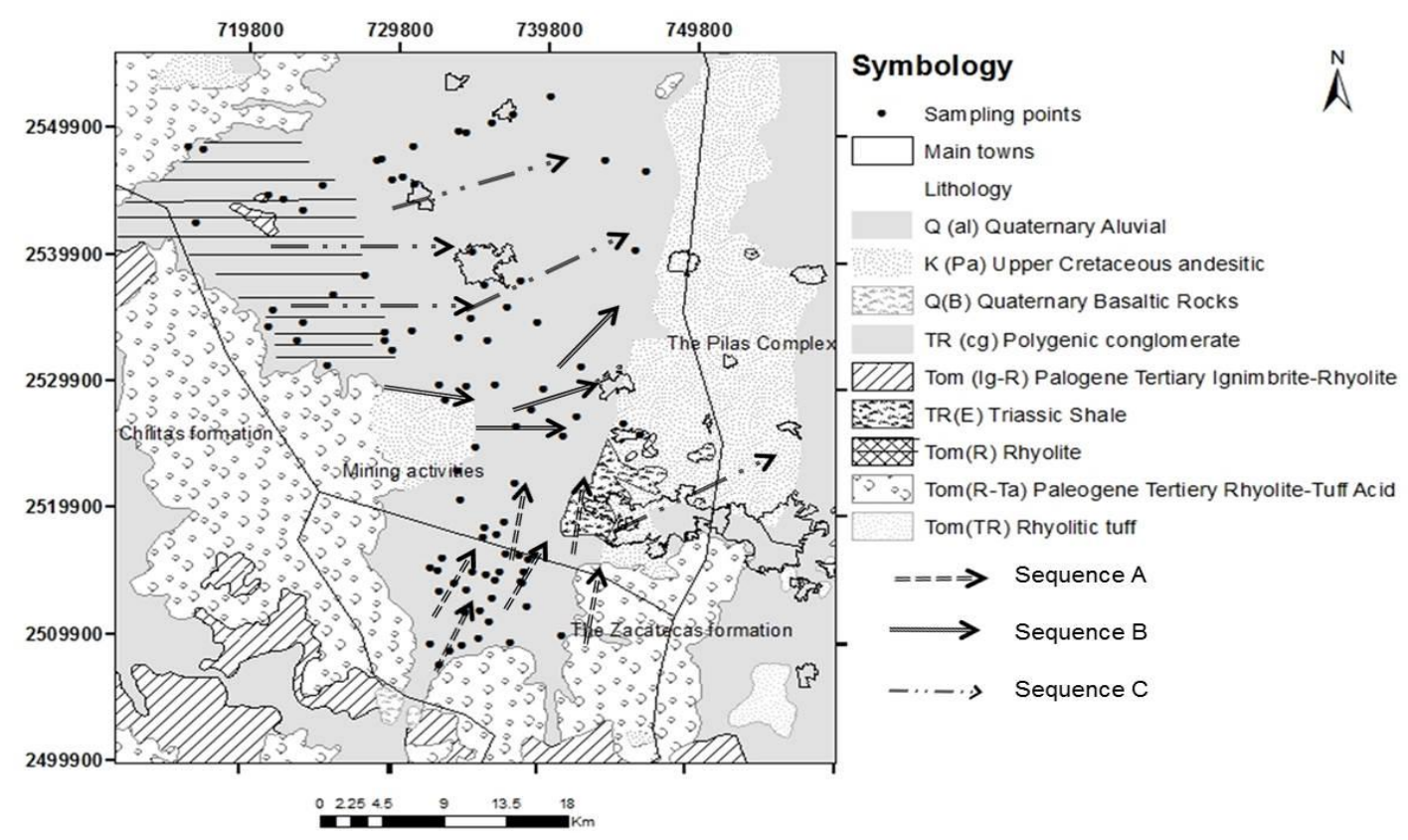

Figure 9. Differentiation of flow patterns (using the Chebotarev sequence)

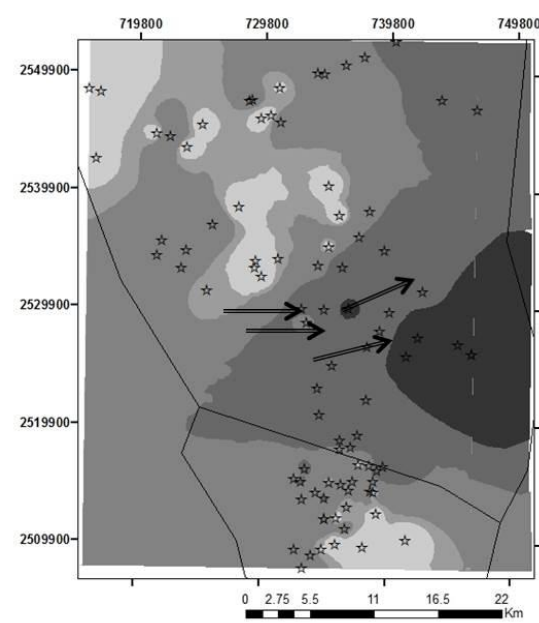

a)

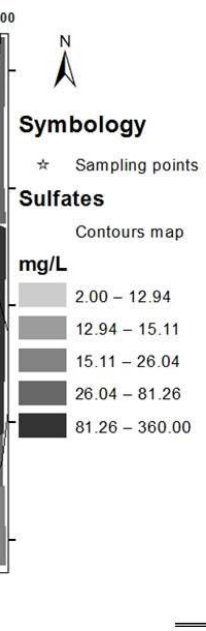

Sequence B

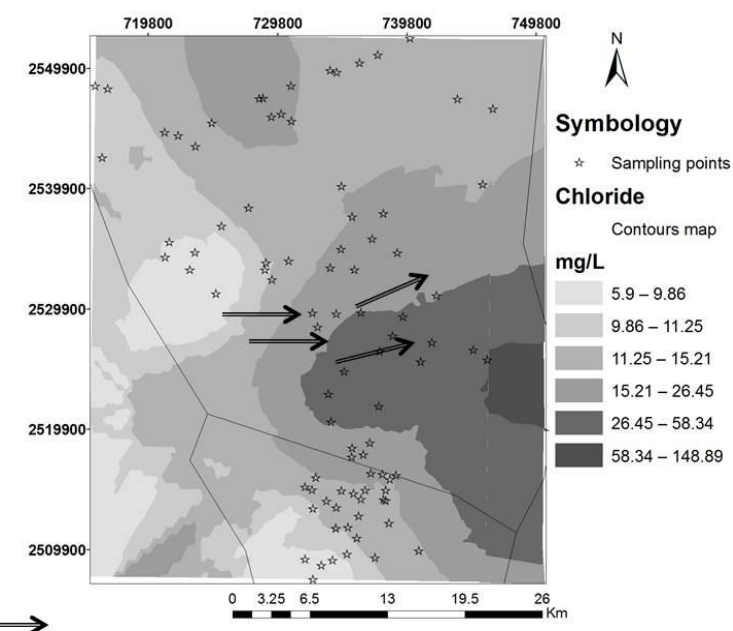

b)

Figure 10. Contours maps a) Sulfate and b) Chloride

\section{Conclusions}

These results show the importance of combining different tools that permit us to understand the dynamics of groundwater. The analysis shows that at some sampled points the arsenic and fluoride concentrations were above the maximum permissible levels established by the WHO for human consumption. The origins for both parameters were defined as follows: 1) anthropogenic-, mining activities for arsenic and the use of phosphate pesticides, for fluoride 2) natural-, geological setting, such as the alluvial quaternary basin that facilitates the dissolution of minerals containing arsenic and where the presence of sodium-bicarbonate water is directly related to the presence of fluoride. 
According to the classification by the US-Salinity Laboratory, most of the groundwater samples fell into the C2-S1 category; this indicates a medium salinity and low sodium content. A few points fell in the C1-S1 category, indicating low salinity and sodium content. However, there are four sampled points at which the results were classified in the C3-S1 category; these represents groundwater with high salinity that is not suitable for many crops. Another analysed parameter was the total hardness. The groundwater was classified from soft to moderately hard, indicating that the total hardness does not represent quality problems. The geochemical interpretation indicates that silicate dissolution, mainly pyroxene, biotite, and albite were the main chemical reactions, and were the source of $\mathrm{Ca}^{2+}, \mathrm{Mg}^{2+}, \mathrm{Na}^{+}, \mathrm{K}^{+}, \mathrm{HCO}_{3}{ }^{-}$and $\mathrm{SiO}_{2}$, whereas for $\mathrm{N}_{-} \mathrm{NO}_{3}{ }^{-}$, the source was anthropogenic activities. The results indicate that groundwater is predominantly characterized by the presence of four hydrogeochemical faces: 1) $\mathrm{Ca}^{2+}$ $\mathrm{HCO}_{3}{ }^{-}$; 2) a mixture between $\mathrm{Mg}^{2+}-\mathrm{Ca}^{2+}-\mathrm{HCO}_{3}{ }^{-}$and $\mathrm{Mg}^{2+}-\mathrm{Ca}^{2+}-\mathrm{SO}_{4}{ }^{2-}$; 3) a mixture between $\mathrm{Ca}^{2+}-\mathrm{Na}^{+}-\mathrm{HCO}_{3}^{-}$and $\mathrm{Ca}^{2+}-\mathrm{Mg}^{2+}-\mathrm{HCO}_{3}^{-}$; and 4) a mixture between $\mathrm{Na}^{+}-$ $\mathrm{HCO}_{3}{ }^{-}$and $\mathrm{Ca}^{2+}-\mathrm{Na}^{+}-\mathrm{HCO}_{3}{ }^{-}$. The distribution of major ions and the presence of the different faces, along with analysis of the Chebotarev sequence, allowed the identification of correlations coefficient, and PCA suggested that the composition and movement of groundwater were influenced by the interaction of water and the rocks in diverse geological conditions.

Three groundwater flow patterns were identified. The first one moved from south to north, which was dissected by a second flow pattern crossing from west to east. There was a third flow pattern from the northwest to northeast that could be a regional flow system with movement beyond the SA. In future work, the use of analytic techniques, such as isotopic hydrology should be considered for identifying the origin of recharge in the different identified flow patterns.

\section{REFERENCES}

[1] Adhikary, P.P.; Chandrasekharam, H.; Chakraborty, D.; Kamble, K. (2010): Assessment of groundwater pollution in West Dheli, India using geostatistical approach. Environmental Monitoring Assessment 167(1-4): 599-615, doi: 10.1007/s10661-0091076-5

[2] Adhikary, P.P.; Dash, C.J.; Chandrasekharan, H.; Rajput, T.B.S.; Dubey, S.K. (2012): Evaluation of groundwater quality for irrigation and drinking using GIS and geostatistics in a peri-urban area of Delhi, India. - Arabian Journal Geosciences 5(6): 1423-1434, doi: 10.1007/s12517-011-0330-7

[3] Ahmad, Dar I.; Sankar, K.; Shafi, T., Ahmad Dar M. (2011): Investigation of groundwater quality in hardrock terrain using Geoinformation System. - Environmental Monitoring Assessment 176(1-4): 575-659, doi: 10.1007/s10661-010-1605-2

[4] Andrade, A.; Stigter, T. (2011): Hydrogeochemical controls on shallow groundwater under agricultural land: case study in central Portugal. - Environmental Earth Sciences 63(4): 809-825, doi: 10.1007/s12665-010-0752-7

[5] Apelo, T.; Heederik, J.P. (2006): Arsenic in Groundwater: A world problem. - IGRAC International Groundwater Resources Assessment Centre, 7-8.

[6] APHA AWWA WPCF. (2006): Standard Methods for the Examination of Water and Wastewater. 20th Ed. - Washington, E.U.A. 
[7] Atkinson, J. (2011): Geochemistry analysis and evolution of Bolson aquifer, basin and range province in the southwestern United States. - Environmental Earth Sciences 64(1): 37-46, doi: 10.1007/s12665-010-0814-x

[8] Brunt, R.; Vathesak, L.; Griffio, J. (2004): Fluoride in groundwater: Probability of occurrence of excessive concentration on global scale. - IGRAC International Groundwater Resources Assessment Centre, 1-4

[9] Carrillo Rivera, J.J.; Cardona, A.; Edmunds, WE. (2002): Use of abstraction regime knowledge of hydrogeological conditions to control high-fluoride concentration in abstracted groundwater: The San Luís Potosí basin, México. - Journal of Hydrology 261(1-4): 4-47.

[10] Chebotarev, II. (1955): Metamorphism of natural water in the crust of weathering. Geochimica et Cosmochimica 8: 22-48.

[11] CONAGUA National Water Comission. (2012): Estadísticas del Agua en México (Statistics on Water in Mexico). - Secretaría de Medio Ambiente y Recursos Naturales, México City, México.

[12] CONAGUA National Water Comission. (2013): Actualización de disponibilidad media anual de agua subterránea (Update annual average availability of groundwater). Zacatecas, Calera aquifer (3210), Benito Juárez aquifer (3225).

[13] Daessle', L.W.; Ruiz-Montoya, L.; Tobschall, H. J.; Chandrajith, R.; Camacho-Ibar, V. F.; Mendoza-Espinosa, L. G.; Quintanilla-Montoya, A. L.; Lugo-Ibarra, K. C. (2009): Fluoride, nitrate and water hardness in groundwater supplied to the rural communities of Ensenada County, Baja California, Mexico. - Environmental Geology 58(2): 419-419, doi: 10.1007/s00254-008-1512-9.

[14] Elangbam, J. K.; Gupta, A.S.; Singh, N.R. (2013): Groundwater quality in Imphal West district, Manipur, India, with multivariate statistical analysis of data. - Environmental Sciences Pollution Research 20(4), 2421-2434.

[15] Escalona-Alcázar, F.J.; Delgado-Argote, L.A.; Nebel, O.; Velasco-Tapia, F.; Weber, B.; Núñez, E.P. (2014): Maturing Arc Signatures Monitored by Trace Element and Hf Isotope Systematics in the Early Cretaceous Zacatecas Volcanic Field, Mexico. - The Journal of Geology 122(5): 549-566, doi: 10.1086/677045

[16] Estrada-Capetillo, B.L.; Ortiz-Pérez, M.D.; Salgado-Bustamante, M.; Calderón-Aranda, E.; Rodríguez-Pinala, C.J.; Reynaga-Hernández, E.; Corral-Fernández, N.E.; GonzálezAmaro, R.; D.P. Portales-Pérez, D.P. (2014): Arsenic and fluoride co-exposure affects the expression of apoptotic and inflammatory genes and proteins in mononuclear cells from children. - Mutation Research/Genetic Toxicology and Environmental Mutagenesis 731(1-2): 27-34, doi.org/10.1016/j.mrgentox.2014.01.006.

[17] FAO Food and Agriculture Organization. (2013): Water Quality Evaluation. http://www.fao.org/docrep/003/T0234E/T0234E01.htm. Access 26/01/14

[18] Fehdi, Ch.; Rouabhia, A.; Baali, F.; Boudoukha, A. (2009): The hydrogeochemical characterization of Morsott-El Aouinet aquifer, Northeastern Algeria. - Environmental Geology 58(7): 1611-1620, doi: 10.1007/s00254-008-1667-4

[19] Garfias, J.; Arroyo, A.; Aravena, R. (2010): Hydrochemistry and origins of mineralized waters in the Puebla aquifer system, México. - Environmental Earth Sciences 59(8): 1789-1805, doi: 10.1007/s12665-009-0161-y 
[20] Gbadebo, A.M.; Taiwo, A.M.; Ayedun, H.; Adeola, A.J. (2012): Geochemical analysis of groundwater quality in Agbara and Environs. - Applied Ecology and Environmental Research 10(3): 375-384.

[21] Gómez, M.L.; Blasarin, M.T.; Martínez, D. E. (2009): Arsenic and fluoride in a loess aquifer in the central area of Argentina. - Environmental Geology 57(1): 143-155, doi:10.1007/s00254-008-1290-4.

[22] Gibrilla, A.; Othee, S.; Akiti, T.T.; Adomako, D.; Ganyaglo, S.Y.; Bam, E.P.K.; Hadisu, A. (2010): Hydrogeochemical and Groundwater Quality Studies in the Northern Part of the Densu River Basin of Ghana. - Journal of Water Resources and Protection 2(12): 1071-1081, doi:10.4236/jwarp.2010.212126.

[23] Horst, A.; Mahlknecht, J.; López-Zavala, M.A.; Mayer, B. (2011): The origin of the salinity and sulfate contamination of groundwater in the Colima State, Mexico, constrained by stable isotopes. - Environmental Earth Sciences 64(7): 1931-1941, doi: 10.1007/s12665-011-1008-x

[24] Hussain, I.; Arif, M.; Hussain, J. (2012): Fluoride contamination in drinking water in rural habitations of Central Rajasthan, India. - Environmental Monitoring Assessment, 184(8): 5151-5158, doi:10.1007/s10661-011-2329-7

[25] INIFAP (2016): Red de Monitoreo Agroclimático del Estado de Zacatecas (Network Monitoring Zacatecas State Agroclimatic). http://zacatecas.inifap.gob.mx/estaciones.php Access 15/09/2016

[26] Jousma, G. (2006): Guideline on: Groundwater monitoring for general reference purposes. - IGRAC International Groundwater Resources Assessment Centre. WMO World Meteorological (WMO), 56-67.

[27] Júnez-Ferreira, HE.; Herrera, GS. (2013): A geostatistical methodology for the optimal design of space-time hydraulic head monitoring networks and its application to the Valle de Queretaro aquifer. - Environmental Monitoring Assessment 185(4): 3527-3549, doi: 10.1007/s10661-012-2808-5

[28] Júnez-Ferreira, HE.; Bautista-Capetillo, CF.; González-Trinidad, J. (2013): Análisis geoestadístico de cuatro iones mayoritarios y arsénico en el acuífero Calera, Zacatecas. (Four statistical analysis major ions and arsenic in the Calera aquifer, Zacatecas) Tecnología y Ciencias del Agua 4: 179-185.

[29] Kolsi, S.H..; Bouri, S.; Hachicha W.; Dhia H.B. (2013): Implementation and evaluation of multivariate analysis for groundwater hydrochemistry assessment in arid environments: a case study of Hajeb Elyoun-Jelma, Central Tunisia. - Environmental Earth Sciences 70(4): 2215-2224, doi:10.1007/s12665-013-2377-0.

[30] Kumar, Ch.; Shashtri, S.; Mukherjee, S. (2011): Integrating multivariate statistical analysis con GIS for geochemical assessment of groundwater in Shiwailks of Punjab, India. - Environmental Earth Sciences 62(7): 1387-1405, doi: 10.1007/s12665-010-06250

[31] Li, P.; Qian, H.; Wu, J.; Zhang, Y.; Zhang, H. (2013): Major Ion Chemistry of Shallow Groundwater in the Dongsheng Coalfield, Ordos Basin, China. - Mine Water and the Environment 32(3): 195-206, doi:10.1007/s10230-013-0234-8

[32] Li, X.; Li G.; Zhang, Y. (2014): Identifying Major Factors Affecting Groundwater Change in the North China Plain with Grey Relational Analysis. - Water 6(6): 15811600; doi:10.3390/w6061581.

[33] Marghade, D.; Malpe, D. B. N.; Subba R. N. (2015): Identification of controlling processes of groundwater quality in a developing urban area using principal component 
analysis. - Environmental Earth Sciences 74(7): 5919-5933, doi:10.1007/s12665-0154616-Z

[34] Pierre, G.; Plumer, L. (2005): Review: Geochemistry and the understanding of groundwater systems. - Hydrogeology Journal 13(1): 263-287, doi: 10.1007/s10040-0040429-y

[35] Rasaouli, F.; Seyed, A.K.P. (2011): Hydrogeochemistry and water quality assessment of the Kor-Sivand Basin, Fars province, Iran. - Environmental Monitoring Assessment 184(8): 4861-4877. doi: 10.1007/s10661-011-2308-z

[36] Rhoades, JD.; Kandiah, A.; Mashali, A M. (1992): The use of saline waters for crop production. - FAO. http://www.fao.org/docrep/t0667e/t0667e05.htm Access 26/11/2015

[37] Saidi, S.; Salem, B.; Hamed, BD.; Brice, A. (2009): A GIS-based susceptibility indexing method for irrigation and drinking water management planning: Application to ChebbaMellouleche Aquifer, Tunisia. - Agricultural Water Management 96(12): 1683-1694, doi:10.1016/j.agwat.2009.07.005

[38] Sappa, G.; Ergul, S.; Ferranti, F. (2014): Water quality assessment of carbonate aquifers in southern Latium region, Central Italy: a case study for irrigation and drinking purposes. - Applied Water Sciences 4(2): 15-128, doi:10.1007/s13201-013-0135-9

[39] SGM Servicio Geológico Mexicano. Cartas Impresas. Zacatecas F13-6. (2014): http://mapserver.sgm.gob.mx/Cartas_Online/geologia/63_F13-6_GM.pdf. Access $15 / 01 / 2014$

[40] Shomar, B.; Fakher, S.A.; Yahya, A. (2010): Assessment of Groundwater Quality in the Gaza Strip, Palestine Using GIS Mapping. - Journal of Water Resource and Protection 2(2): 93-104, doi:10.4236/jwarp.2010.22011

[41] Subba, R.N. (2006): Seasonal variation of groundwater quality in a part of Guntur District, Andhra Pradesh, India. - Environmental Geology 49(3): 413-429, doi: 10.1007/s00254-005-0089-9

[42] Subba, R.N. (2011): High-fluoride groundwater. Environmental Monitoring Assessment 176(1-4): 637-645 DOI 10.1007/s10661-010-1609-y

[43] Sung A, J. (2012): Geochemical occurrences of arsenic and fluoride in bedrock groundwater: a case study in Geumthesan County, Korea. - Environmental Geochemical Health 34(1): 43-54, doi:10.1007/s10653-011-9411-5

[44] Tweed, S.; Leblanc, M.; Webb, J.; Maciek, L. (2007): Remote sensing and GIS for mapping groundwater recharge and discharge areas in salinity prone catchments, southeastern Australia. - Hydrogeology Journal 15(1): 75-96, doi: 10.1007/s1004-0060129-x (1)

[45] Uddameri, V.; Honnungar H.; Hernandez E. A. (2014) Assessment of groundwater water quality in central and southern Gulf Coast aquifer, TX using principal component analysis. - Environmental Earth Sciences 71(6): 2653-2671, doi:10.1007/s12665-0132896-8

[46] US-Environmental Protection Agency. Quality Criteria for Water. (1986): The Gold Book

http://water.epa.gov/scitech/swguidance/standards/criteria/aqlife/upload/2009_01_13_crit eria_goldbook.pdf.

[47] Vandernbohode, A.; Lebbe, L. (2012): Groundwater chemistry patterns in the phreatic aquifer of central Belgian coastal plain. - Applied Geochemistry 27(1): 22-36, doi:10.1016/j.apgeochem.2011.08.012 
[48] Veyna, A.I. (2014): Monitoreo de la calidad del agua en los sistemas de cosecha de lluvia en el estado de Zacatecas (Monitoring water quality in rainwater harvesting systems in the state of Zacatecas). Master Thesis. Universidad Autónoma de Zacatecas. México, 47.

[49] WHO. (2011):Guidelines for drinking water quality, 4th edn. World Health Organization, Geneva. http://www.who.int/water_sanitation_health/water-quality/en/ Access $21 / 01 / 2014$

[50] Zhang, X.; Qian, H.; Chen, J.; Qiao, L. (2014): Assessment of Groundwater Chemistry and Status in a Heavily Used Semi-Arid Region with Multivariate Statistical Analysis. Water 6(8): 2212-2232, doi:10.3390/w6082212

\section{ELECTRONIC APPENDIX}

This manuscript has an electronic appendix with field data. 